\title{
ANALISIS PENGARUH GOOD CORPORATE GOVERNANCE TERHADAP KINERJA PERUSAHAAN PERBANKAN DI INDONESIA
}

\author{
Ika Listyawati , Ida Kristiana \\ Prodi Akuntansi Universitas AKI Semarang, Prodi \\ Akuntansi Universitas Muhammadiyah Semarang
}

ika.listyawati@unaki.ac.id

Riwayat Artikel: Dikirim April 2018; Diterima Maret 2018 ; Diterbitkan Maret 2018

Corporate governance is still a major problem during financial periods such as Indonesia. Especially, financial institutions have carried out reforms to improve goals and stakeholders. The purpose of this study is to measure corporate governance and in a banking environment that is specific to corporate governance.

The independent variables used in this study are ownership structures consisting of controlling shareholder ownership, foreign ownership, government ownership; the size of the board of directors; the size of the board of commissioners; independent commissioner; CAR. The sample of this study is a general banking company located in Indonesia which is listed on the Indonesia Stock Exchange (BEI) for the period 2010-2014. This research data is derived from the annual report of the bank (annual report) for the period 20102014 which is obtained from the website of each of the banks, the Indonesian Banking Directory, Indonesian Capital Market Directory (ICMD). The analytical method used is multiple linear regression in accordance with the research objectives that analyze the effect of independent variables on the dependent variable. The purposive sampling method is used to determine the sample of choice. From this method, get 26 samples of commercial banks.

The results of the analysis found that Controlling Shareholder Ownership (OWN) and Government Ownership (GOV) showed a negative relationship not significant to banking performance. However, for Foreign Ownership (FOR), Board of Directors Size (BOD), Board of Commissioners Size (BOC), Proportion of Independent Commissioners (INDEP) shows a positive and significant relationship. Then for the variable Capital Adequacy Ratio (CAR) there is a significant negative relationship.

Keywords: Corporate Governance, Company Performance, Controlling Shareholder Ownership, Government Ownership, Foreign Ownership, Size of the Board of Directors, Size of the Board of Commissioners, Proportion of Independent Commissioners and Capital Adequacy Ratio. 


\section{PENDAHULUAN}

\section{Latar Belakang}

Dunia keuangan yaitu perbankan memiliki peran yang sangat penting dalam memenuhi laju pertumbuhan ekonomi suatu negara. Tingginya peredaran uang dan perdagangan bebas menjadikan sektor perbankan sebagai sektor penting dalam perdagangan karena bank memiliki fungsi intermediasi, yaitu menghimpun dana dari masyarakat untuk kemudian disalurkan kepada masyarakat kembali. Namun, fungsi perbankan sebagai intermediasi keuangan dirasakan belum begitu optimal. Hal ini dapat dilihat dari buruknya kinerja perbankan pada saat krisis ekonomi, seperti banyak bank yang sulit memenuhi ketentuan Capital Adecuacy Ratio(CAR) dan Batas Maksimum Pemberian Kredit (BMPK) sebagaimana yang telah ditentukan oleh regulator.

Guna memperkuat industri perbankan, maka upaya yang dilakukan sesuai dengan enam pilar Arsitektur Perbankan Indonesia (API) yaitu dengan meningkatkan kualitas tata kelola perusahaan atau yang sering dikenal dengan istilah Good Corporate Governance(GCG). Perhatian investor terhadap GCG sama besarnya dengan perhatian investor terhadap kinerja keuangan perusahaan. GCG sendiri juga mempunyai fungsi untuk menumbuhkan kepercayaan investor terhadap perusahaan. Penerapan GCG akan mencegah kesalahan dalam pengambilan keputusan dan perbuatan menguntungkan diri sendiri sehingga secara otomatis akan meningkatkan nilai perusahaan yang tercermin pada kinerja keuangan.

Kondisi ataupun kinerja keuangan perusahaan dapat tercermin pada laporan keuangan melalui analisis rasio-rasio keuangannya. Analisis rasio keuangan adalah cara menganalisis dengan menggunakan perhitungan-perhitungan perbandingan atas data kuantitatif yang ditunjukkan dalam laporan keuangan. Laporan keuangan adalah hasil akhir dari proses akuntansi yang disusun dengan tujuan untuk memberikan informasi keuangan suatu perusahaan. Informasi keuangan tersebut dapat digunakan oleh para pemakai untuk pengambilan keputusan investasi. Return on asset(ROA) merupakan salah satu rasio yang digunakan untuk mengukur tingkat profitabilitas perusahaan. Return on asset digunakan untuk mengukur besarnya laba bersih yang dapat diperoleh dari operasional perusahaan dengan menggunakan seluruh kekayaannya. Tinggi rendahnya ROA tergantung pada pengelolaan asset perusahaan yang menggambarkan efisiensi operasional perusahaan.

\section{METODE PENELITIAN}

Metode regresi linier berganda merupakan uji regresi, yang mana menggunakan variabel independen lebih dari satu dan variabel dependen satu.Variabel independen dalam penelitian ini adalah kepemilikan pemegang saham pengendali, = kepemilikan asing, kepemilikan pemerintah, ukuran dewan direksi, ukuran dewan komisaris, proporsi komisaris independen, dan rasio kecukupan modal (CAR). Persamaan yang dibentuk dengan menggunakan regresi linier berganda adalah sebagai berikut :

$$
\begin{aligned}
\text { CPik }= & \alpha+\beta 1 \text { OWNit }+\beta 2 \text { FORit }+ \\
& \beta 3 \text { GOVit }+\beta 4 \text { BODit }+\beta 5 \\
& \text { BOCit }+\beta 6 \text { INDBit }+\beta 7 \\
& \text { CARit }+€
\end{aligned}
$$

untuk i menunjukan time $=1,2, \ldots, n$, dan $k=$ 


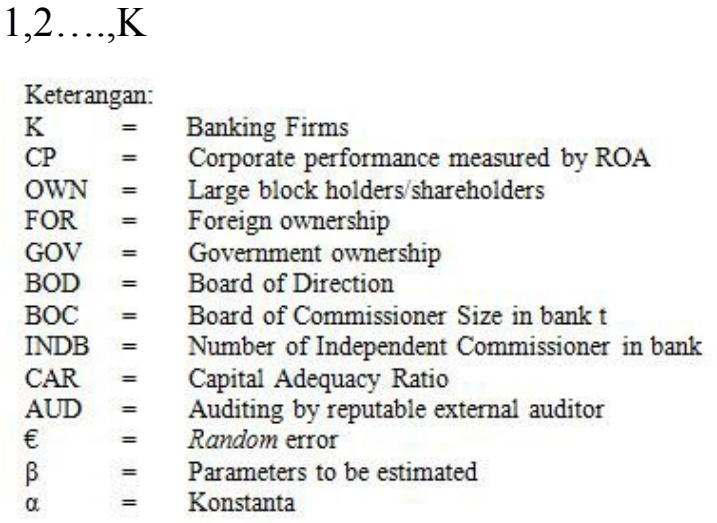

\section{HASIL DAN PEMBAHASAN}

Model regresi linier berganda yang baik adalah tidak mengalami otokorelasi, dengan syarat bahwa $1<\mathrm{DW}<3$.

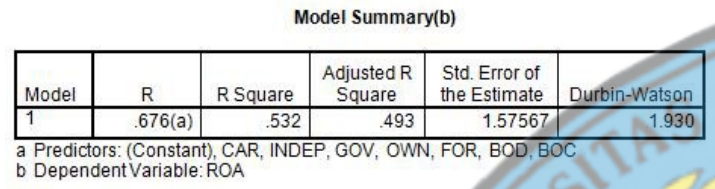

Nilai Adjusted $\mathrm{R}^{2}$ adalah sebesar 0,493 . Berarti variabel bebas dalam penelitian ini mampu menjelaskan varians ROA sebesar 49,3 \% dimana selebihnya yaitu $50.7 \%$ dijelaskan oleh faktor diluar variabel tersebut. Standar Error of estimate (SEE) menunjukkan nilai 1,57567, hal ini menunjukkan nilai yang kecil sehingga dapat disimpulkan model regresi layak digunakan untuk memprediksi variabel dependen. Sementara itu, nilai $\mathrm{R}$ sebesar 0,676 menunjukkan hubungan antara variabel dependen yaitu ROA dengan variabel independen yaitu $O W N$, FOR, GOV, BOD, BOC, INDP, dan CAR.

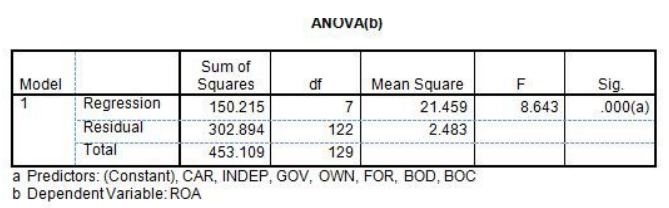

Berdasarkan uji signifikan ssimultan (Uji-F) sebesar 8,643 dengan taraf signifikansi sebesar 0,000 $(<0,05)$. Hasil tersebut menunjukkan bahwa secara bersama-sama variable bebas dalam penelitian ini mempunyai pengaruh yang signifikan terhadap ROA.

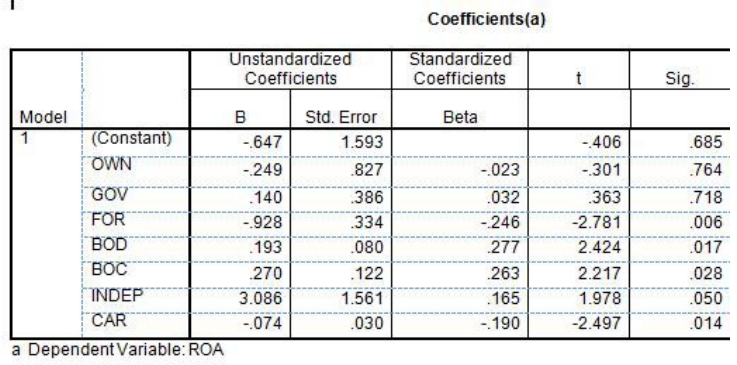

Hasil uji signifikan parsial (Uji-t) regresi statistik-t terlihat bahwa variabel kepemilikan asing (FOR), jumlah Dewan Direksi (BOD), jumlah Dewan Komisaris (BOC), proporsi Komisaris Independen (INDB), rasio CAR menunjukkan hubungan yang signifikan terhadap variable dependennya (ROA) dengan taraf signifikansi 5\%. Sedangkan untuk variabel lainnya yaitu OWN dan GOV tidak berpengaruh secara signifikan terhadap variable ROA karena probabilitas diatas 5

$\%$.

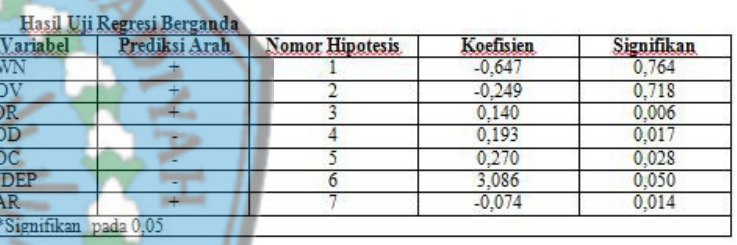

\section{Variabel Kepemilikan Pemegang Saham Pengendali (OWNER)}

Hasil pengujian statistik dengan uji-t menunjukkan bahwa variable OWNER berpengaruh negatif terhadap kinerja perbankan terlihat dari nilai $\beta=-0,647$ artinya bank yang memiliki pemegang saham pengendali akan memiliki ROA yang lebih rendah0,647dibanding bank yang tidak memiliki pemegang saham pengendali. Berdasarkan hasil uji statistik didapatkan nilai $\mathrm{t}=-0,301$ dan $\mathrm{Sig}=0,764$ $(\mathrm{Sig}>0,05)$. Estimasi yang dihasilkan tidak sesuai dengan hipotesa yang diajukan dalam penelitian ini, di mana Kepemilikan Pemegang Saham Pengendali memiliki pengaruh positif terhadap ROA. Hasil pengujian statistik menunjukkan besarnya nilai probabilita sebesar 0,764> 0,05 (alpha 5\%). Hasil penelitian ini tidak mendukung teori yang ada bahwa 
pemegang saham pengendali dapat lebih banyak melakukan monitoring terhadap pihak manajemen perusahaan dan meningkatkan nilai perusahaan. Adanya monitoring yang cukup tinggi membuat manajer merasa diawasi sehingga tidak maksimal dalam bekerja dan karena banyaknya pihak pengendali menyebabkan banyak keinginan yang harus dipenuhi dari para pemegang saham pengendali perusahaan, hal ini menyebabkan manajemen tidak bisa berfokus dalam meningkatkan kinerja perusahaan (Belkhir, 2005).

\section{Variabel Kepemilikan Pemerintah (GOV)}

Hasil pengujian statistik dengan uji-t menunjukkan bahwa variable GOV berpengaruh positif tidak signifikan terhadap kinerja perbankan terlihat dari nilai $\beta=0,140$ artinya bank yang terdapat kepemilikan pemerintah sebesar 5\% atau lebih akan memiliki nilai ROA lebih rendah sebesar 0,140 dibandingkan dengan bank yang tidak terdapat kepemilikan pemerintah. Hasil pengujian statistik menunjukkan besarnya nilai probabilita sebesar $0,032<0,05($ alpha $5 \%$ ). Oleh karena itu disimpulkan pada tingkat kepercayaan $95 \%$ terdapat pengaruh negatif dan tidak signifikan antara kepemilikan asing terhadap ROA. Hasil penelitian ini mendukung teori yang ada bahwa tersebarnya mayoritas kepemilikan saham kepada kepemilikan pemerintah (government ownership) maka pelaksanaan monitoring para pemegang saham kepada pihak manajemen perusahaan menjadi lemah karena pemegang saham tidak mempunyai insentif dan kemampuan untuk memonitor manajemen. Hasil pengujian ini sependapat dengan penelitian yang dilakukan Yulius Ardy Wiranata dan Yeterina Widi Nugrahanti (2013) dimana hasil studi mereka memperlihatkan bahwa kepemilikan asing tidak berpengaruh terhadap kinerja perusahaan. Hal ini mungkin disebabkan perusahaan milik asing memiliki tujuan lain. Tidak seperti perusahaan swasta, yang mana menghasilkan profit sebesar-besarnya.Hal ini terbukti dengan ditunjukkannya pengaruh yang negatif dan tidak signifikan atas pengaruh kepemilikan asing terhadap perbankan di mana nilai $\mathrm{t}=0,365$ dan Sig $=0,813)$.

\section{Variabel Kepemilikan Asing (FOR)}

Hasil pengujian statistik dengan uji-t menunjukkan bahwa variabel FOR memiliki pengaruh positif terhadap kinerja perbankan terlihat dari nilai $\beta=$ 0,928 artinya bank yang terdapat kepemilikan asing sebesar 5\% atau lebih akan memiliki ROA yang lebih rendah sebesar 0,928 dibandingkan dengan bank yang tidak terdapat kepemilikan asing sebesar 5\% atau lebih. Hasil pengujian statistik menunjukkan besarnya nilai probabilita sebesar 0,006 $<0,05$ (alpha $5 \%$ ). Oleh karena itu disimpulkan pada tingkat kepercayaan $95 \%$ terdapat pengaruh positif dansignifikan antara kepemilikan asing terhadap ROA atau bisa juga disimpulkan bahwa hanya terjadi kecenderungan pada saat terdapat kepemilikan asing maka akan menaikkan ROA. Hasil pengujian ini juga mendukung penelitian yang dilakukan oleh Barth, Caprio Jr, danLevine (2002) mengenai peran kepemilikan asing dalam kinerja bank. Hasil studi mereka memperlihatkan bahwa semakin besar kepemilikan oleh asing cenderung mengalami perkembangan kinerja yang membaik.

Temuan ini juga mendukung hasil penelitian yang dilakukan oleh Muliaman Hadad, Agus Sugiarto, Wini Purwanti, Joni Hermanto, dan Bambang Arianto (2003), menggunakan data empiris 131 bank yang ada di Indonesia memberikan kesimpulan bahwa kinerja bank tidak memiliki kaitan erat dengan siapa pemiliknya.

\section{Variabel Ukuran Dewan Direksi (BOD)}

Hasil pengujian statistik dengan uji-t menunjukkan bahwa variabel BOD 
berpengaruh positif terhadap kinerja perbankan terlihat dari nilai $\beta=0,193$ artinya jika BOD meningkat 1 , maka ROA akan meningkat sebesar 0.193(19,3\%). Hasil pengujian statistik menunjukkan besarnya nilai probabilita sebesar $0,017<$ 0,05 (alpha 5\%) maka disimpulkan hipotesa null ditolak. Oleh karena itu disimpulkan pada tingkat kepercayaan $95 \%$, terdapat pengaruh positif signifikan antara ukuran dewan direksi dengan ROA atau dengan kata lain dapat disimpulkan bahwa pada saat BOD meningkat maka akan meningkatkan ROA (berdasarkan hasil uji statistik didapatkan nilai $\mathrm{t}=2,424$ dan $p=0,017(p<0,05))$. Hasil penelitian ini mendukung teori yang ada bahwa peningkatan ukuran dan diversitas dari dewan direksi berpengaruh terhadap kinerja bank karena akan memberikan manfaat bagi perusahaan dengan terciptanya network dengan pihak luar perusahaan dan menjamin ketersediaan sumber daya (pfefer, 1973; Pearce \& Zahra, 1992 dalam Faizal, 2005).

Temuan ini mendukung hasil penelitian Suranta dan Machfoedz (2003).Hasil penelitian menunjukan bahwa hubungan ukuran dewan direksi dan nilai perusahaan adalah linier dan positif yang berarti bahwa nilai perusahaan dipengaruhi oleh ukuran dewan direksi.

\section{Variabel Ukuran Dewan Komisaris} (BOC)

Hasil pengujian statistik dengan uji-t menunjukkan bahwa variabel BOC berpengaruh positif terhadap kinerja perbankan terlihat dari nilai $\beta=0,270$ artinya jika BOC meningkat 1 maka akan meningkatkan ROA sebesar 0,270 (27\%). Hasil pengujian statistik menunjukkan besarnya nilai probabilita sebesar $0,028<$ 0,05 (alpha 5\%) maka disimpulkan hipotesa null ditolak. Oleh karena itu disimpulkan pada tingkat kepercayaan 95\% terdapat pengaruh positif signifikan antara ukuran dewan komisaris dengan ROA atau dengan kata lain dapat disimpulkan bahwa pada saat BOC meningkat maka akan menaikkan ROA (berdasarkan hasil uji statistikdidapatkan nilai $\mathrm{t}=2,217$ dan $p=0,028(p<0,05))$. Hasil penelitian ini mendukung teori yang ada bahwa ukuran dewan komisaris menentukan tingkat keefektifan pemantauan kinerja bank.

Dewan komisaris yang semakin banyak akan membuat dampak bagi karyawan bahwa merekasemakin terkontrol sehingga meminimalkan mereka melakukan perbuatan yang akan menguntungkan diri mereka sendiri.

\section{Variabel Proporsi Komisaris Independen (INDB)}

Hasil pengujian statistik dengan uji-t menunjukkan bahwa variabel INDB berpengaruh positif terhadap kinerja perbankan terlihat dari nilai $\beta=3,086$ yang artinya jika proporsi Komisaris Independen terhadap BOC meningkat sebesar 1 maka akan menaikkan ROA sebesar 3,086 (308,6\%). Hasil pengujian statistik menunjukkan besarnya nilai probabilita sebesar $0,050<0,05$ (alpha 5\%) dengan nilai $\mathrm{t}=1,978$ maka disimpulkan hipotesa null ditolak. Oleh karena itu disimpulkan pada tingkat kepercayaan $95 \%$ terdapat pengaruh positif signifikan antara proporsi komisaris independen terhadap BOC dengan ROA atau dapat disimpulkan bahwa terjadi kecenderungan yang signifikan bahwa pada saat proporsi komisaris independen terhadap BOC meningkat akan menaikkan ROA. Hasil penelitian ini mendukung teori yang ada bahwa proporsi dewan luar berhubungan positifdengan kinerja perusahaan (Wardhani, 2006).

\section{Variabel Rasio Kecukupan Modal (CAR)}

CAR merupakan suatu persyaratan cadangan rasio kecukupan modal yangditetapkan pemerintah sebagai bentuk pemantauan peraturan (regulator) terhadapkinerja perbankan. Hasil pengujian statistik dengan uji-t menunjukkan bahwa variabel CAR berpengaruh negatif terhadap kinerja 
perbankan terlihat dari nilai $\beta=-0,074$ artinya jika CAR naik sebesar $1 \%$ maka ROA turun sebesar 0,074 (7,4\%). Hasil pengujian statsitik menunjukkan besarnya nilai probabilita sebesar $0,014<$ 0,05dengan nilai $\mathrm{t}=-2,497$ sehingga dapat disimpulkan hipotesa null ditolak. Oleh karena itu disimpulkan pada tingkat kepercayaan 95\% terdapat pengaruh negatif signifikan antara variabel CAR dan ROA atau dengan kata lain bisa disimpulkan bahwa terjadi kecenderungan pada saat CAR meningkat maka akan menurunkan ROA.

Hasil penelitian ini mendukung teori yang ada yang berasal dari KomiteBassel menyiratkan bahwa pemantauan peraturan (regulator) yang dikeluarkanoleh bank sentral atau pemerintah mempengaruhi kinerja perbankan terutamadalam profitabilitas, melalui persyaratan cadangan dan atau Rasio KecukupanModal (Brigham dan Erhardt, 2005). Namun hasil penelitian menunjukkan bahwa pengaruh negatif antara variabel CAR dengan ROA bisa jadi disebabkan karena tidak selarasnya tujuan dari ditetapkannya ketentuan oleh regulator terhadap tujuan bank. Tujuan BI menetapkan nilai CAR minimum bagi bank adalah untuk mengantisipasi potensi kerugian sesuai profil risiko Bank. Namun, hal ini tidak dapat meningkatkan kinerja perbankan di Indonesia karena adanya kewajiban CAR justru membuat bank harus menyimpan sejumlah dana sehingga tidak bisa digunakan untuk operasional yang dapat meningkatkan laba bank tersebut.

\section{KESIMPULAN}

Berdasarkan hasil pengujian dan pembahasan mengenai pengaruh variabel kepemilikan pemegang saham pengendali (OWNER), kepemilikan asing (FOR), kepemilikan pemerintah (GOV), ukuran dewan direksi (BOD), ukuran dewankomisaris (BOC), komisaris independen (INDB), dan CAR terhadap kinerja perusahaan perbankan yang diproksikan melalui ROA, maka peneliti dapat meringkas penemuan pada penelitian ini adalah sebagaiberikut:

1. Model regresi berganda yang digunakan dalam penelitian ini cukup layak, karena lolos dari empat pengujian terhadap asumsi klasik, yaitu ujimultikolineritas, uji autokolerasi, uji heterokedasitas dan uji normalitas.

2. Dari hasil pengujian hipotesis pertama, kepemilikan pemegang saham pengendali (OWN) secara statistik tidak signifikan terhadap ROA sebagaiproksi kinerja perusahaan. Hal ini dibuktikan dengan nilai signifikansi0,764 (> 0,05). Sedangkan nilai t hitung $(-0,301)$ yang menunjukkan bahwa OWNER tidak berpengaruh secara signifikan terhadap kinerja perbankan.

3. Dari hasil pengujian hipotesis kedua, kepemilikan Asing (FOR) secara statistik tidak signifikan terhadap ROA sebagai proksi kinerja perusahaan. Hal ini dibuktikan dengan nilai signifikansi $0,718 \quad(>0,05)$. Sedangkan nilai t hitung $(0,363)<\mathrm{t}$ tabel $(1,6575) \quad$ yang menunjukanbahwa FOR tidak berpengaruh secara signifikan terhadap kinerja perbankan.

4. Dari hasil pengujian hipotesis ketiga, kepemilikan Pemerintah (GOV) secara statistik berpengaruh signifikan terhadap ROA sebagai proksi kinerja perusahaan. Hal ini dibuktikan dengan nilai signifikansi $0,006 \quad(<0,05)$. Sedangkan nilai $\mathrm{t}$ hitung $(-2,781)>\mathrm{t}$ tabel $(1,6575)$ yang menunjukan bahwa GOV berpengaruh secara signifikan terhadap kinerja perbankan.

5. Dari hasil pengujian hipotesis keempat, ukuran dewan direksi (BOD)secara statistik signifikan terhadap ROA sebagai proksi kinerjaperusahaan. Hal ini dibuktikan dengan nilai signifikansi $0,017(<$ 
$0,05)$. Sedangkan nilai t hitung $(2,424)$

$>\quad \mathrm{t}$ tabel $(1,6575)$ yang menunjukanbahwa BOD memiliki pengaruh yang positif signifikan terhadap kinerja perbankan.

6. Dari hasil pengujian hipotesis kelima, ukuran dewan komisaris (BOC)secara statistik signifikan terhadap ROA sebagai proksi kinerjaperusahaan. Hal ini dibuktikan dengan nilai signifikansi $\quad 0,028 \quad(<\quad 0,05)$. Sedangkan nilai $\mathrm{t}$ hitung $(2,217)>\mathrm{t}$ tabel $\quad(1,6575) \quad$ yang menunjukanbahwa BOD memiliki pengaruh yang positif signifikan terhadap kinerja perbankan.

7. Dari hasil pengujian hipotesis keenam, komisaris independen (INDB)secara statistik positif signifikan terhadap ROA sebagai proksi kinerjaperusahaan. Hal ini dibuktikan dengan nilai signifikansi $0,050 / 2$ (< $0,05)$.Sedangkan nilai t hitung $(1,978)$ $>\mathrm{t}$ tabel $(1,6575)$ yang menunjukanbahwa INDB berpengaruh positif signifikan terhadap kinerja perbankan.

8. Dari hasil pengujian hipotesis ketujuh, rasio kecukupan modal (CAR)secara statistik signifikan terhadap ROA sebagai proksi kinerjaperusahaan. Hal ini dibuktikan dengan nilai signifikansi $0,014 \quad(<\leq 0,05)$. Sedangkan nilai $\mathrm{t}$ hitung $(-2,497)>\mathrm{t}$ tabel $(1,6575) \quad$ yang menunjukanbahwa CAR memiliki pengaruh yang negatif signifikan terhadap kinerja perbankan.

\section{DAFTAR PUSTAKA}

Arifin, Zaenal. 2005. Hubungan Antara Corporate Governance dan Variabel Pengurang Masalah Agensi.Jurnal Siasat Bisnis, Vol.1, No.10, Juni 2005, Hal. 39-55.

Anggraeni, Ayu Septi. 2011. Analisis Granger Causality Terhadap Kinerja Sosial Dan Kinerja Keuangan
Perusahaan.Skripsi. Fakultas Ekonomi Universitas Diponegoro. Semarang.

Bai,C.,Q.Liu, J.Lu.,F.Song.,\& J.Zhang. 2003. Corporate Governance and Market Valuation in China.Working Paper. University of Hongkong

Bank Indonesia, 1998.Surat Keputusan Direksi Bank No.30/277/KEP/DIR tanggal 19 Maret 1998 tentang Cara Penilaian Tingkat Kesehatan Bank. Jakarta.

Bank Indonesia, 2000.Peraturan BI No.2/27/PBI/2000 tanggal 15 Desember 2000 tentang Bank Umum.Jakarta.

Bank Indonesia. 2003.Peraturan BI No 5/25/PBI/2003 tentang Penilaian Kemampuan dan Kepatuhan (Fit and Proper Test). Jakarta.

Bank Indonesia. 2006. Peraturan BI No 8/4/PBI/2006 tentang Penerapan GCG Bagi Bank Umum. Jakarta.

Bank Indonesia. 2007. Surat Edaran BI No. 9/12/DPNP tanggal 30 Mei 2007 tentang Perihal Pelaksanaan Good Corporate Governance Bagi Bank Umum. Jakarta.

Bank Indonesia. 2013. Surat Edaran BI No. 15/15/DPNP tanggal 29 April 2013 perihal Pelaksanaan GCG bagi Bank Umum.Jakarta.

Bank for International Settlements, Basle Committee on Banking Supervision, (1998) Framework for internal control systems in banking organisation

Barth, James R., G. Caprio, Jr., and R. Levine. 2002. Banking System Around the Globe : Do Regulation and Ownership Affect Performance and Stability?.

Beiner, S.,W. Drobetz, F. Schmid dan H. Zimmermann, 2003. Is Board Size An Independent Corporate Governance 
Mechanism?.http://www.wwz. Inibaz.chllcofi/ publications/ papers/ 2003/06.03.pdf

Brigham, E.F. \& M.C. Erhardt. 2005. Financial Management Theory and Practice, 11 th Edition, Ohio : South Western

Charter, R dan Dark, F., 1998, Underwriter Reputation, Innitial Returns, and Long-Run Performance of IPO Stocks. Journal of Finance, Vol. 53, No. 1,pp 285-311

Caprio,G., L.Leuven., R.Levine. 2003. Governance and Bank Valuation.Working PaperNo.10158, National Bure of Economic Research

Chemmanur, Thomas J. dan Paeglis Immants, 2004, Management Quality, Certification, and Initial Public Offering. Journal of Financial Economics, Vol. 76, No. 1, pp 331-368.

Darmawati, Deni dkk. 2005. Hubungan Corporate Governance, Kinerja Perusahaan dan Reaksi Pasar. Jurnal Riset Akuntansi Indonesia.Vol.8, No.1, Hal.65-81.

Diandono, Hudan. 2012. Pengaruh Mekanisme Good Corporate Governance (GCG) Terhadap Kinerja Keuangan Pada perusahaan Yang Masuk Kelompok Jakarta Islamic Index (JII) Periode 2006-2011.Skripsi. Yogyakarta: Universitas Islam Negeri Sunan Kalijaga.

Eldomiaty, T.L., \& C,J. Choi.. 2003.Bank's Orientation and Performance in Shareholders Business Systems. Working Paper Series, Available at SSRN: http://ssrn.com/abstract $=462600$

Erlina, Sri Mulyani, 2007. Metodologi Penelitian Bisnis : Untuk Akuntansi dan Manajeme. Cetakan Pertama USU Press, Medan
Faisal, 2005, Analisis Agency Cost, Struktur Kepemilikan dan Mekanisme Corporate Governance.Jurnal Riset Akuntansi Indonesia, Vol.8, No.2, Hal. 175-190.

Fama,E.F. dan M.C Jensen. 1983. Separation of Ownership and Control.Journal of Law and Economics, Vol. 26. Hal. 301-325

Firmansyah, 2006.Analisis Hubungan Struktur Kepemilikan Dengan Kinerja Keuangan Perusahaan Perbankan Persero dan Perusahaan Perbankan Swasta Nasional Go Publik.Skripsi.Fakultas Ekonomi Universitas Islam Indonesia Yogyakarta. (Dipubliskan)

Ghozali, Imam. 2001. Analisis Multivariate dengan Program SPSS.Badan Penerbit Universitas Diponegoro, Semarang.

Ghozali, Imam. 2009. Ekonometrika. Teori, Konsep dan Aplikasi dengan SPSS 17. Badan Penerbit Universitas Diponegoro, Semarang.

Gujarati, Damomar. 1991.Ekonometrika Dasar. Penerbit Erlangga. Jakarta. Terjemahan: Sumarno Zain

Gunarsih, Tri. 2003. Struktur Kepemilikan Sebagai Salah Satu Mekanisme Corporate Governance. Kompak Nomor 8.

Hadad, M., A. Sugianto., W. Purwanti., J. Hermanto, \& B. Arianto. 2003Kajian Mengenai Kepemilikan Bank di Indonesia. Research Paper Direktorat Penelitian dan Pengaturan Perbankan, Bank Indonesia, No 8/5, Bank Indonesia, 2003, Hal 1-15.

Hardikasari, Eka, 2011. Pengaruh Penerapan Corporate Governance Terhadap Kinerja Keuangan pada Industri Perbankan yang Terdaftar di Bursa Efek Indonesia (BEI) Tahun 
2006-2008. Skripsi,Fakultas Ekonomi, Universitas Diponegoro Semarang.

Jensen, M.C. and W.H. Meckling. 1976.

Theory of the Firm: Managerial

Behavior, Agency Cost and

Ownership Structure.Journal

ofFinancial Economics 3 (4): 305-360.

Klapper, Leora F. and I. Love.

2002.Corporate Governance, Investor

Protection and Performance in

Emerging Markets. World

Bank.Working Paper.http://ssrn.com.

Lastanti, Hexana Sri. 2004. Hubungan

Struktur Corporate Governance

dengan Kinerja Perusahaan dan

Reaksi Pasar. Konferensi Nasional

Akuntansi: Peran Akuntan dalam

Membangun Good Corporate

Governance.

Levine, R. 2003.The Corporate

Governance of Banks, Global

Corporate Governance Forum. World

Bank. Washington, DC.

Macey, J.R. and M. O'Hara. 2003.The

Corporate Governance of Banks.

Federal Reserve Bank of New York

Economic PolicyReview, Vol. 9 No.1,

pp. 91-107

Niinimaki,J.P. 2001.Inter-temporal

Diversification in Financial

Intermediation. Journal of Banking

and Finance, 25, pp 965-991

Sari, Irmala.2010. Pengaruh Mekanisme

Good Corporate Governanceterhadap

Kinerja Perbankan Nasional.Skripsi.

Fakultas Ekonomi Universitas

Diponegoro. Semarang.

Sekaredi, Sawitri. 2011. Pengaruh

Corporate Governance Terhadap

Kinerja Keuangan Perusahaan (Studi

Pada Perusahaan yang Terdaftar di

LQ45 Tahun 2005-2009). Skripsi.

Tidak Dipublikasikan. Semarang:

Universitas Diponegoro Semarang.
Siallagan, Homonagan dan M.Machfoedz. 2006. Mekanisme Corporate Governance, Kualitas Laba dan Nilai Perusahaan.Simposium Nasional Akuntansi IX, Padang 23-26 Agustus 2006.

Sugiyono. 1999. Statistik untuk Penelitian Bisnis. Bandung: Alfabeta

Sukamulja, Sukmawati. 2004. Good Corporate Governance di Sektor Keuangan: Dampak Good Corporate Governance Terhadap Kinerja Keuangan. Vol.8.No.1. Juni 2004. Hal 1-25.

Suranta, Eddy., M. Machfoedz. 2003, Analisis Struktur Kepemilikan, Nilai Perusahaan, Investasi dan Ukuran Dewan Direksi.Simposium Nasional Akuntansi VI.

http://www.emeraldinsight.com/

http://investing.businessweek.com/

http://www.idx.go.id/ 